\title{
JUDICIAL REVIEW OF STATE HEALTH PLANS AFTER THE HEALTH PLANNING AND RESOURCES DEVELOPMENT AMENDMENTS OF 1979
}

The American health care industry has historically operated free of extensive governmental control. ${ }^{1}$ In the last decade, however, the federal government has sought to require the health care industry to develop its services according to carefully conceived plans. ${ }^{2}$ With this goal in mind, Congress enacted the National Health Planning and Resources Developinent Act of $1974,{ }^{3}$ an ainbitious attempt to coordinate federal, state, and inunicipal efforts at regulatimg the development of health care facilities. ${ }^{4}$ The heart of the Act was its requirement that each state enact a certificate of need $(\mathrm{CON})^{5}$ prograin by 1980.6 Under

1. For a brief description of the history of government controls on health care, see Wing \& Craige, Health Care Regulation: Dilemma of a Partially Developed Public Policy, 57 N.C. L. REv. $1165,1185-93$ (1979).

2. The rationale for planning in the health care field is discussed in Blunstcin \& Sloan, Health Planning and Regulation Through Certificate of Need: An Overview, 1978 UTAH L. REv. 3, 3-8.

3. Pub. L. No. 93-641, 88 Stat. 2225 (1975) (codified at 42 U.S.C. $\$ \S 300 k-300 t$ (1976)).

4. See Wing \& Craige, supra note 1, at 1190. See generally Blumstein \& Sloan, supra note 2, at 8-19, 34-37.

5. A CON is a document that grants permission to inake a capital expenditure in the health care industry. It is tantamount to a hicense enabling the apphicant legally to construct a new facility or to purchase additional equipment. See 42 U.S.C. $\S 300 \mathrm{n}(7)$ (1976).

6. Id. $\S 300 \mathrm{~m}-2(\mathrm{a})(4)(\mathrm{A})$. The particular prograin adopted must be approved by the Secrctary of Health and Human Services (formerly the Secretary of Health, Education, and Welfare). Id. $\$ 300 \mathrm{in}-1$. States failing to establish acceptable CON prograuns risk losing federal funding under the National Health Planning and Resources Developinent Act itself, the Drug Abuse Office and Treatment Act of 1972, 21 U.S.C. $\$ 1101$ (1976), the Community Mental Health Centers Act, 42 U.S.C. $\$ 2689$ (1976), and the Comprehensive Alcohol Abuse and Alcohohsin Prevention, Treatment, and Rehabilitation Act of 1970, 42 U.S.C. $\$ 4541$ (1976). See 42 U.S.C. $\$ 300 \mathrm{~m}(d)(2)$ (1976). As of January, 1979, 40 states and the District of Columbia had adopted CON programs. H.R. REP. No. 190, 96th Cong., Ist Sess. 42 (1979). Since then nine other states have adopted CON programs. See IDAHo CODE $\$ \S 39-4901$ to -4914 (1980); IND. CoDE $\$ \S 16-1-3.2-1$ to -11 (1980); Miss. Code ANN. $\$ \$ 41-7-187$ to -209 (1979); Mo. ANN. STAT. $\$ \S 197.300-365$ (Vernon 1979); Neb. Rev. Stat. $\$ \$ 71-5801$ to -5872 (1979); N.H. Rev. STAT. ANN. $\$ \S 151-C$ : 1-16 (1979); Pa. Stat. ANN. tit. 35, \$\$ 448.701-.711 (Purdon 1979); UtaH Code ANN. § 26-34-1 to -21 (1979); VT. STAT. ANN. tit. 18, $\$ \S 2400-2416$ (1979). For a inore detailed discussion of how CON programs operate, see Schonbrun, Making Certificate of Need Work, 57 N.C. L. REv. 1259, 1263-66 (1979). 
such a program, a person wishing to make a capital expenditure in the health care industry in excess of $\$ 150,000$ must first obtain a certification from a state agency that the capital outlay is necessary. ${ }^{7}$ In 1979 Congress amended the Act by passing the Health Planning and Resources Developinent Amendments. ${ }^{8}$

Under the Act and its amendments, local quasi-governmental bodies known as Health Systems Agencies (HSAs) are responsible for promulgating health care development plans for their respective regions. ${ }^{9}$ A Statewide Health Coordmating Council consolidates the regional plans into a simgle plan for the entire state. ${ }^{10}$ The state health plan sets out criteria pursuant to which a State Health Planning and Development Agency (SHPDA) renders decisions regarding particular CON applications. Before the 1979 amendments, the state agencies were required only to consider-not necessarily to follow-state liealtl plans when rendering CON decisions. ${ }^{11}$

Because the state healtl plans were advisory under the original Act, they were not subject to direct judicial review. ${ }^{12}$ Under the 1979 amendments, however, CON decisions must "be consistent witl" state health plans. ${ }^{13}$ This note suggests that Congress has elevated these state health plans from mere advisory guidelines to full-fledged administrative rules. The note concludes that courts are no longer limited to reviewing individual CON denials; they may now review the state health plans themselves.

\section{From Guidelines to Regulations}

Administrative pronouncements, other than statements relevant only to a particular adjudication, fall imto two legally significant categories: rules or regulations, which carry "the force of law,"14 and less bimding statements, such as interpretations, releases, opinions, or advisory letters. ${ }^{15}$ When agencies issue full-fledged rules or regulations,

7. 42 U.S.C. $\$ 300 \mathrm{~m}-6$ (1976). An outlay is necessary, for example, if it is to be used to purchase equipment that does not duplicate similar equipment already serving the community.

8. Pub. L. No. 96-79, 93 Stat. 606 (codified at 42 U.S.C. $\$ \S 300 \mathrm{k}-300 \mathrm{n}$ (Supp. III 1979).

9. See 42 U.S.C. $\$ 300 /-1(b)(3)(B)(i i)(1976)$.

10. Id. $\$ 300 \mathrm{~m}-3(\mathrm{c})$.

11. See notes 20-21 infra and accompanying text.

12. See note 19 infra and accompanying text.

13. 42 U.S.C. $\$ 300 \mathrm{~m}-6(\mathrm{a})(5)$ (Supp. III 1979).

14. See, e.g., Pollock v. General Fin. Corp., 552 F.2d 1142, 1144-45 (5th Cir.), cert. denied, 434 U.S. 891 (1977); Barry Laboratories, Inc. v. Wisconsin State Bd. of Pharmacy, 26 Wis. 2d 505, 513-17, 132 N.W.2d 833, 837-39 (1965).

15. See 2 K. Davis, Administrative Law Treatise $\$ \$ 7: 4$, :5 (2d ed. 1979). The precise degree of authoritative weight necessary to qualify an administrative statenent as a rule or regulation is difficult to articulate. Professor Davis notes that attempts to distinguish rules from guide- 
they exercise quasi-legislative power. "In prescribing such a regulation," explained one court, "the tribunal in effect legislates within the boundaries marked out for its action by legislative enactınent." 16 General statements of agency policy or opinion are not legislative in nature; they possess little or no prospective binding force and thus fail to qualify as rules or regulations. ${ }^{17}$ The distinction between rules and less binding declarations is often important because agencies must promulgate rules according to established procedures and criteria 18 but are typically free to issue less binding administrative pronouncements at will. The distimction is also important because a court will review the validity of a rule, looking both to its substance and the procedure of its promulgation. Less binding statements, on the other hand, are not themselves reviewable; a party must wait until the agency has followed its statement with specific action affecting his rights before lie may seek judicial redress. ${ }^{19}$

lines typically yield a "fuzzy product." $1 \mathrm{~K}$. DAvis, ADMINISTRATIVE LAW TREATISE § 501, at 290 (1st ed. 1958). One court suggests that the distinction such efforts have produced "is enshrouded in considerable smog." Noel v. Chapınan, 508 F.2d 1023, 1030 (2d Cir.), cert. denied, 423 U.S. 824 (1975).

16. Utah Hotel Co. v. Industrial Comm'n, 107 Utah 24, 31, 151 P.2d 467, 470 (1944).

17. See Pacific Gas \& Elec. Co. v. Federal Power Comm'n, 506 F.2d 33, 38 (D.C. Cir. 1974). The court stated:

A general statement of policy is the outcome of neither a rulemaking nor an adjudication; it is neither a rule nor a precedent but is merely an announcement to the public of the policy which the agency hopes to implement in future rulemakings or adjudications. A general statement of policy, like a press release, presages an upcoining ruleinaking or announces the course which the agency intends to follow in future adjudications.

Id. (footnotes omitted). A case that illustrates the operation of these concepts in the health care industry is Cheshire Convalescent Center, Inc. v. Commission on Hosps. \& Health Care, 34 Conn. Supp. 225, 386 A.2d 264 (C.P. 1977). The Connecticut SHPDA had issued what it characterized as a guideline stating a state maximum of 70 nursing hoine beds per 1,000 people age 65 or over. 386 A.2d at 266. Because it considered the ceiling a guideline rather than a regulation, the agency had not complied with the applicable rulennaking provisions of the state's adininistrative procedure act. $386 \mathrm{~A} .2 \mathrm{~d}$ at 270 . The appellant corporation applied for a CON permitting it to construct a new nursing home that would have provided beds in excess of the guideline. The agency denied the application, and the applicant challenged the denial in court contending that the guideline was in fact a regulation and therefore void because the agency had issued it in a procedurally improper fashion.

The trial court agreed with the applicant, finding that the "consistent application" of the 70beds-per-1,000-population limitation indicated that the guideline was in fact a regulation, despite the agency's contrary claracterization. 386 A.2d at 269 . The court reasoned that because the standard was "obvionsly an agency statement of general applicability that implements, interprets or prescribes law or policy," and "has a substantial impact on the rights and obligations of parties who may appear before the agency in the future, it is a substantive or legislative rule requiring compliance with the notice and learing provisions of the [state's administrative procedure act]." 386 A.2d at 270-71.

18. See 2 K. DAvis, supra note $15,87: 4$, at 17 (2d ed. 1979).

19. See, e.g., Cochran v. Planning Bd., 87 N.J. Super. 526, 210 A.2d 99 (1965). 
Health plans issued before the 1979 amendments were merely nonbinding administrative declarations. The original Act specified that the SHPDA was to "administer a State certificate of need program which applies to new imstitutional healtl services proposed to be offered or developed within the State . . . In performing its functions under this paragraph the [SHPDA] shall consider recommendations made by health systems agencies . . .."20 The Act made no mention of any direct, bimding role for state and regional liealth plans. The plans enjoyed only an advisory status. ${ }^{21}$ As a result, citizens could not directly challenge these advisory health plans under the original Act. Rather, a party desiring to invest im the health care industry would apply for a certificate of need and appeal an adverse CON decision instead of challenging the health plan that might have influenced that decision. 22

The 1979 amendments provide a conduit through whicl litigants may now attack health plans directly. The amended Act reads: "each decision to issue a certificate of need . . . shall, except in emergency circumstances that pose a threat to public health, be consistent with the State health plan ...."23 This new requirement of consistency between health plans and individual CON decisions makes the plans sufficiently binding to transform them into full administrative rules. ${ }^{24}$

The literal meaning of the phrase "shall . . . be consistent with" suggests substantial prospective impact, and the existence of an exception for emergencies further indicates that Congress envisioned compliance with health plans in typical, non-emergency situations. Congress carefully considered the exception for emergencies. The origmal Senate bill imcluded the exception, while the House version did not. ${ }^{25}$ The conference committee considered this discrepancy and opted for the Senate version. ${ }^{26}$ That Congress recognized a need to sanction ex-

20. 42 U.S.C. $\$ 300 \mathrm{~m}-2(\mathrm{a})(4)$ (B) (1976).

21. See, e.g., Page v. Capital Medical Center, Inc., 371 So. 2d 1087, 1088-89 (Fla. App. 1979); FLA. STAT. $\$ \S 381.493(3)(\mathrm{h}), .494(5)(a)$ (1973); Weiner, Participatory Procedure and Political Support for Hospital Cost Containment Programs: Limits of Open Administrative Process, 57 N.C. L. REv. 1197, 1254-55 (1979). In fact, HSAs were not even obligated to follow their own plans. Id. 1255 n.230.

22. There are reported cases that follow this scenario in virtually all jurisdictions with operating CON programs. See, e.g., Tarpon Springs Gen. Hosp. v. Office of Community Medical Facilities, 366 So. 2d 185 (Fla. App.), cert. dismissed, 374 So. 2d 101 (Fla. 1979); Charter Medical Corp. v. Mississippi Health Planning \& Dev. Agency, 362 So. 2d 180 (Miss. 1978). See also Suburban Medical Center v. Olathe Community Hosp., 226 Kan. 320, 597 P.2d 654 (1979).

23. 42 U.S.C. $\$ 300 \mathrm{~m}-6(\mathrm{a})(5)$ (B) (Supp. III 1979) (emphasis added).

24. See note 15 supra.

25. S. REP. No. 309, 96th Cong., Ist Sess. 81 (1979) (conference committee report).

26. Id. 
pressly the emergency exception imdicates an intent that individual CON decisions be consistent with the policies set forth in the provisions of the relevant liealth plans. ${ }^{27}$

Congress's use of the word "consistent" elsewhere in the legislation supports this imterpretation. The original Act stated that a local health plan was satisfactory only if it is was "consistent with" certaim national health policy guidelines promulgated by the Department of Health, Education and Welfare (now the Department of Health and Human Services). ${ }^{28}$ The 1979 amendments eliminated this requirement. ${ }^{29}$ The legislative history of the amendment reveals that Congress made the change to allow variations im state plans for umique local needs, ${ }^{30}$ indicatimg that Congress imtended the requirement for consistency between documents under this statute to be a strict command with few exceptions. Accordingly, the consistency requirement imposed by the 1979 amendments makes state health plans sufficiently binding on later CON decisions to qualify the plans as full administrative rules. As such, they may now be subject to direct procedural and substantive attack. ${ }^{31}$

27. This interpretation of the statute is consistent with the canon of statutory construction expressio unius est exclusio alterius ("to specify one thing is to exclude all others"). See generally 2A J. Sutherland, Statutes and Statutory Construction $\$ 47.23$ (4th ed. 1973). Congress's express permission to deviate from state health plans in emergencies implicitly proscribes deviation when no emergency exists.

28. National Health Planning and Resources Devclopment Act of 1974, Pub. L. No. 93-641, $\S 1513(\mathrm{~b})(2), 88$ Stat. 2236 (1975) (current version at 42 U.S.C. \$ 300/-2 (Supp. III 1979)).

29. Pub. L. No. 96-79, §115(b)(1), (2), (c)(2), (d)(1), (2), (e), (i)(1), § 129, 93 Stat. 607-609, 629-30 (1979) (codified at 42 U.S.C. $\$ 300 /-2(b)(2)$ (Supp. III 1979)).

30. H.R. REP. No. 190, supra note 6, at 69 (1979).

31. See note 18 supra. The elevation of state liealth plans from advisory to mandatory status parallels a potential change in the status of the so-called "master plans" involved in regional planning and zoning. See generally Haar, The Master Plan: An Impermanent Constitution, 20 LAW \& Contemp. Prob., Summer, 1975, at 353. Master plans are regional zoning plans that planning and zoning commissions draw to guide them in making specific decisions. In most instances they are mainly advisory, leaving planning and zoning commissions frec to deviate from their standards when making particular rulings. Id. 364-65. Hence, they resemble pre-1979 health plans.

Individuals cannot directly cliallenge master plans im court, just as individuals could not directly challenge health plans in court under the original Act. Plaimtiffs have, howevcr, attempted direct challenges to master plans. In Cochran v. Planning Bd. of Summit, 87 N.J. Super. 526, 210 A.2d 99 (1965), for example, landowners attacked a newly issued master plan alleging that it deprived thein of property without due process of law by arbitrarily lowering their property values, and that it was adopted without the ten days' notice required by the act that establislred the inaster planning scheine. Id. at 529, 210 A.2d at 101. The Cochran court held that the plaintiffs could not directly challenge the plan, reasoning that "a inaster plan is of no force and effect until it is adopted by the governing body of the municipahity. . . . [T] he plan . . . is not binding, either on governinent or individual." Id. at 534-35, 210 A.2d at 104. The court observed that "[u]ntil implementation of the proposal is atteinpted, there can be no purpose in an adjudication by this court at this time." Id. at 541, 210 A.2d at 108. 


\section{The Right to Judicial Review of State Health Plans}

\section{A. Existence of the Right.}

The starting point for determining whether a particular rule is subject to judicial review is the statute that authorizes the rule. The statutes that directly authorize state health plans are the state statutes that implement the federal legislation. ${ }^{32}$ These state statutes inay not contravene the federal legislation; otherwise, the Secretary of Health and Human Services must cut certain federal funding to the state. ${ }^{33}$ It is therefore proper to gauge the extent to which state health plans are subject to judicial review by referring to the federal legislation. Because, as demonstrated immediately below, Congress envisioned such review in amending the National Health Planning and Development Act, the state implementimg legislation inust provide for it. ${ }^{34}$

The Act, as amended in 1979, contains no express provision for judicial review of state health plans. Such an omission, however, does not militate against judicial review; when no administrative renedy exists, there is a presumption in favor of judicial review when Congress is silent regarding the issue. ${ }^{35}$ The Supreme Court has stated, for exainple, that "judicial review of a final agency action by an aggrieved person will not be cut off unless there is persuasive reason to beheve that

The advisory status of master plans, like the advisory status of state health plans under the origimal Act, removed them from judicial scrutiny. If these plans gained mandatory characteristics, they would then be subject to judicial scrutiny: "If a master plan has a direct legal effect, it might be possible to attack it in court rather than attacking an action implementing the plan." $D$. Hagman, Public Planning and Control of Urban and Land Development 332-33 (1973). It is this direct legal effect that now characterizes state health plans, thereby opening the courtroom door.

32. See note 6 supra and accompanying text.

33. See note 6 supra.

34. This analysis breaks down, of course, if state legislatures deviate from federal mandates. It is imcumbent upon the Secretary to eusure that this does not occur. Should the Secretary fail to carry out his duties under the Act, private parties may sue to enforce the Act. See Texas Acorn v. Texas Area 5 Health Syss. Agency, 559 F.2d 1019 (5th Cir. 1977) (an imdividual has the right to challenge the Secretary's designation of a particular body as the region's HSA; the designated body allegedly did not satisfy the Act's requirement that it represent the region's population); Aldamuy v. Pirro, 436 F. Supp. 1005 (N.D.N.Y. 1977) (same).

A recent decision suggests that state courts, interpretimg ambiguous state statutes, will look to the federal guidelines under the National Health Planning and Resources Development Act in order to interpret the state statute consistently with the federal act. Iowa State Dep't of Health v. Hertko, 282 N.W.2d 744 (lowa 1979). When the state statute is clear on its face, however, state courts will apply it as written, even though it is not fully consistent with the federal act. See Metzler v. Sisters of Charity Health Servs. Corp., 227 Kan. 53, 605 P.2d 100 (1980).

35. Stark v. Wickard, 321 U.S. 288 (1944). The Stark Court wrote that "the silence of Congress as to judicial review is . . not to be construed as a demal of authority to the aggrieved person to seek appropriate relief in the federal courts in the exercise of their general jurisdiction." Id. at 309 . 
such was the purpose of Congress." 36 The Revised Model State Administrative Procedure Act, which twenty-eight states and the District of Columbia had adopted as of January 1981, ${ }^{37}$ takes a similar position. It expressly sanctions judicial review of any rule that was promulgated im a procedurally improper fashion or that illegally impairs rights. ${ }^{38}$ An express exception is thus necessary to prevent courts from reviewing the validity of any particular set of rules. ${ }^{39}$

Nothing im the National Health Planning and Resources Development Act or its 1979 amendments indicates congressional opposition to judicial review of state health plans. Neither does the subject matter of those plans render review inappropriate. In fact, the 1979 amendments expressly authorize judicial review of individual CON determinations, ${ }^{40}$ and even before these amendments were effective state courts permitted judicial review of CON determinations whether or not the state's enabling legislation expressly sanctioned it. ${ }^{41}$ Similarly, courts may now be expected to review the state health plans pursuant to which these CON decisions are made.

\section{B. Substance of the Right.}

Courts invalidate administrative rules on a variety of grounds. ${ }^{42} \mathrm{~A}$

36. Abbott Laboratories v. Gardner, 387 U.S. 136, 140 (1967). Professor Davis states that regulations are subject to some form of judicial review in the absence of "affirmative indication of legislative intent in favor of unreviewability" or of "some special reason for unreviewability growing out of the subject matter or the circumstances." $4 \mathrm{~K}$. DAvIS, supra note $15, \S 28.07$, at 31 (1st ed. 1958).

37. See 14 Uniform Laws ANn. 357 (West Supp. 1981).

38. See Model State Administrative Procedure Act, $\S 3,7$ (1980).

39. Congress has made such an express exeinption in the health care development arena. Section 1122 of the Social Security Act, 42 U.S.C. $\S 1320 \mathrm{a}-1$ (1976), prohibits various federal health care reimburseinent paynents (primcipally Medicare and Medicaid) for services furnished by facilities constructed or purchased without certificates of need. The Secretary of Health and Human Services decides when to deny these reimbursements. Id. $\$ 1320 \mathrm{a}-1$ (d). Section 1122 declares: "A determination by the Secretary under this section shall not be subject to administrative or judicial review.” Id. $\$ 1320$ a-1(f). See also Hollingsworth v. Califano, 447 F. Supp. 872 (N.D. Miss. 1979).

40. See 42 U.S.C. $\S 300 \mathrm{in}-1$ (b)(13)(A) (Supp. III 1979).

41. See Charter Medical Corp. v. Mississippi Health Planning \& Dev. Agency, 362 So. $2 d 180$ (Miss. 1978), in which an SHPDA had denied a CON application, and state law did not expressly provide for judicial review. The court permitted the apphicant to challenge the SHPDA's decision: "Where there is no provision for appeal and injured parties do not have a full, plain, complete and adequate remedy at law, the chancery court has jurisdiction for judicial review of the actions of such board or agency." Id. at 182.

42. For a comprehensive discussion of the scope of review of administrative rulemaking, see 2 F. Cooper, State Administrative Law ch. XX (1965); K. Davis, Administrative Law of THE SEVENTIES $\$ \S 29.01-1$ to -8 (1976). 
rule may have been promulgated im a procedurally improper fashion; ${ }^{43}$ it may violate a constitutional right; ${ }^{44}$ or it may exceed the agency's statutory authority or involve an error of law or an abuse of discretion. ${ }^{45}$ The extent to which a court will inquire into any of these allegations depends on the appropriate degree of agency discretion, the rationale advanced to invalidate the rule, and the confidence of the judge in scrutinizmg the agency's actions. ${ }^{46}$

A court is likely to invalidate a state health plan if health planners failed to follow prescribed procedures in adopting the plan. The federal legislation requires, for example, that the local HSAs conduct public hearings on proposed plans and provide for written and oral argument by interested individuals. ${ }^{47}$ The hearings must be advertised in at least two local newspapers one inonth in advance. ${ }^{48}$ Failure to follow these procedures, assuming the state has adopted them, renders the resultant health plan invalid. ${ }^{49}$

Litigants will face several obstacles when they attempt to attack the substance of the plans. Courts apply a deferential standard when reviewing the substance of a rule: the rule is vahd unless the agency's action was arbitrary and capricious. ${ }^{50}$ The arbitrary-and-capricious standard has been applied in reviewing rules issued by SHPDAs, pursuant to which the SHPDA made CON determinations. These rules served the same function as the new state health plans: to set out policies to guide CON decisions. In Cooper River Convalescent Center, Inc. v. Dougherty, ${ }^{51}$ an SHPDA issued a rule placing a moratorium on the construction of new nursing homes. A corporation applied for a CON allowing construction of such a facility, and the SHPDA denied the

43. See, e.g., Foltz v. City of Indianapolis, 234 Ind. 656, 130 N.E.2d 650 (1955); Ziegenbalg v. Mayor \& Township Comm., 77 N.J. Super. 417, 186 A.2d 699 (1962).

44. See, e.g., Del Buono v. Board of Zoning Appeals, 143 Conn. 673, 124 A.2d 915 (1956).

45. See, e.g., Albert v. Gogebic County Pub. Hosp. Bd. of Trustees, 341 Mich. 344, 67 N.W.2d 244 (1954); Rogers Constr. Co. v. Hill, 235 Or. 352, 384 P.2d 219 (1963); Eways v. Reading Parking Auth., 385 Pa. 592, 124 A.2d 92 (1956) (dicta).

46. See generally $2 \mathrm{~F}$. CoOPER, supra note 42 , ch. XX.

47. See 42 U.S.C. \& $300 l-2$ (b)(2) (Supp. III 1979).

48. Id. These requirements go further than Model State Administrative Procedure Acr $\& 3(a)$ (1980), which requires only twenty days notice. The Model Act, however, provides for direct mailing of notice to interested persons. Id.

49. "If the statute enjoins upon the agency a specified course of procedure to be followed in connection with the adoption and filing of rules, any substantial deviation from the required procedure results in an invalidation of the rule." 2 F. COOPER, supra note 42, at 786.

A state that has not adopted the federally required procedures faces the loss of federal funds. See note 6 supra. See also note 34 supra. A state that has adopted the procedures must follow thein for the health plan to be valid.

50. See, e.g., United Hunters Ass'n v. Adams, 36 N.J. 288, 292, 177 A.2d 33, 35 (1962).

51. 133 N.J. Super. 226,336 A.2d 35 (1975). 
application on the authority of its rule. The applicant filed suit challenging the validity of the moratorium. The court reasoned that the state legislation that authorized the SHPDA to promulgate rules designed to contain the cost of medical care by eliminating unnecessary services deserved liberal application to avoid inpairing the agency's ability to carry out its task: "Unless an administrative regulation is clearly ultra vires on its face, the person attacking it must overcone a strong presuinption of validity."52 Instead of examining in detail whether the agency's moratorium was proper, the court cursorily held that the corporation had failed to overcone this strong presumption of validity. ${ }^{53}$

State health plans will carry a similar presuinption of validity because of the wide discretion vested in the health planners who set up the plan. This discretion is evident from an examination of the priorities that health planners must follow when drafting the plans. Health plans should, for example, prolnote "activities for the prevention of disease," proinote "the developinent and use of cost-saving technology," identify and eliminate "duphicative or unneeded services and facilities," and strengthen "competitive forces in the health services industry wherever competition and consumer choice can constructively serve . . . to advance the purposes of quality assurance, cost effectiveness, and access." 54

Identifying how such amorphous goals are best achieved is a difficult task, frequently requiring exercise of an expert's discretion. This is especially true with regard to the goals embraced by the federal legislation because several of these goals are inherently contradictory. For instance, duplicative facilities inay, under certain circumstances, strengthen competition. ${ }^{55}$ It is thus difficult to apply anything reseinbling black-letter standards to particular health plan provisions. Accordingly, parties challenging health plans on such substantive grounds face the difficult task of convincing the court that sufficient reason exists to strike down the agency's reconciliation of those competing goals.

In Shell Oil Co. v. Illinois Pollution Control Board ${ }^{56}$ a state environmental protection act, like the federal law that gives rise to state health plans, contained a number of general considerations for a state agency to take into account before promulgating pollution control reg-

\footnotetext{
52. Id. at $232,336 \mathrm{~A} .2 \mathrm{~d}$ at 39 .

53. Id.

54. 42 U.S.C. $\$ 300 \mathrm{k}-2$ (1976).

55. See id. $\S 300 \mathrm{k}-2(\mathrm{~b})(3)$.

56. 37 Ill. App. 3d 264, 346 N.E.2d 212 (1976).
} 
ulations. ${ }^{57}$ For example, the agency was to consider the technical feasibility and economic reasonableness of its pollution abatement rules. ${ }^{58}$ A petroleum refiner petitioned the court for direct review of an agency rule relating to noise pollution, alleging that the agency had given improper weight to feasibility considerations when it promulgated a noise pollution rule. ${ }^{59}$ The court summarized its views as follows:

The broad requirement that the [agency] "take into account" certain factors in promulgating its pollution control regulations reflects a legislative recognition of the complexities of pollution control technology and of the differing levels of sophistication of control methods associated with various types of pollution. The requirement ... is a flexible one and of necessity requires that a great deal of discretion be exercised by the [agency]. 60

The requirements that health planners must take into account under the federal legislation are similarly broad and flexible.

The second reason that courts will hesitate to invalidate state health plans on substantive grounds is that the composition of HSAs suggests that they were ineant to exercise great discretion, particularly in balancmg coinpeting goals. The governing bodies of these local agencies inust represent various factions within the lay and professional communities in their respective regions. Fifty to sixty percent of the members of each governing board must be lay representatives of the principal socio-economic groups within the region. ${ }^{61}$ The remainder of the inembership must represent the medical professions and must live within the region. ${ }^{62}$

These compositional requirements indicate that Congress envisioned that HSAs would exercise broad discretion. If the tasks delegated to those agencies were merely perfunctory (and therefore easily reviewable in court), input from various constituencies would not be important. The federal legislation commits the reconciliation of conflicting goals and policies to these agencies in inuch the same fashion as the Constitution commits this task to Congress. ${ }^{63}$

57. Ill. ANN. Stat. ch. 111 1/2, § 1027 (Smith-Hurd 1977).

58. Id.

59. 37 Ill. App. 3d at 269, 346 N.E.2d at 217. Similarly, an aggrieved CON applicant might challenge the health plan pursuant to which his application was denied, alleging that the plan improperly fails to permit the additional competition that his health care facility would create.

60. Id. at 274,346 N.E.2d at $22 \mathrm{I}$.

61. 42 U.S.C. $\$ 300 l-1$ (c) (1976).

62. Id. In Texas Acorn v. Texas Area 5 Health Syss. Agency, 559 F.2d 1019, 1026 (5th Cir. 1977), the court examined the allegation that the Secretary of Health, Education and Welfare improvidently certified an unrepresentative HSA. It asserted jurisdiction to hear such claims, but held that the Secretary's decision was not arbitrary and capricious.

63. Conceivably, a state statute could be viewed as committing the exercise of this discretion to the Statewide Health Coordinating Council (SHCC), which assimilates the various lealth sys- 
Substantive review of state health plans will not, of course, be impossible. Judges have in the past heightened the intensity of their review under arguably analogous circumstances. A good example concerns rate-review proceedings under New Jersey's Health Care Facilities Planning Act. ${ }^{64}$ The state's SHPDA is empowered to set Blue Cross-Blue Shield and Medicaid reimbursement rates for hospitals within the state. One recent case before the New Jersey Supreme Court involved the denial of a rate increase request. ${ }^{65}$ Justice Handler, in a concurring opinion, noted that courts should be "mindful that the problems of providing health care services and facilities are complex and controversial and that the Legislature has seen fit to commit the effectuation of the public policy in this area to the judgment of admmistrative specialists."66 Nevertheless, he explained that New Jersey courts often apply a standard of review more exacting than the arbitrary-and-capricious standard 67 -one that requires "that agency action proceed upon an evidential foundation and that the grounds of decision be fully revealed . . . ."68 Specifically, agency action in the health care field must be

supported in the record by evidence which can fairly be regarded as adequate and rehable, taking into account the purposes of the governmental effort, the nature of the administrative function, the coinplexity of the subject matter, the type and quality of evidence customarily available in the health care field, and the need for ad-

tems plans into a state health plan, rather than to the HSAs themselves. See generally 42 U.S.C. $\S 300 \mathrm{~m}-3$ (Supp. III 1979). This result could obtain, for example, because HSAs are frequently private corporations. See id. $\S 300 /-1$ (b)(1). If HSAs, unlike SHCCs, are not agencies of the state, delegating such discretion to them arguably constitutes an unconstitutional delegation of legislative power.

Although the composition of SHCCs is not necessarily as proportionately representational as HSAs, SHCCs are designed to represent both lay and professional interests. The governor of each state may independently appoimt up to $40 \%$ of his state's SHCC, and a majority of these appointees inust represent the lay public. The governor appoints the balance of the SHCC from nominees supplied by each HSA. Id. $\$ 300 \mathrm{~m}-3$. Presumably, these latter appoimtees represent their respective HSAs, which in turn represent the lay and professional communities. Moreover, at least 50 percent of the total composition of each SHCC must represent the lay rather than the professional community within the state. $I d$.

64. 26 N.J. Stat. ANN. ch. $2 \mathrm{H} \S 26$ (West Supp. 1980).

65. In re 1976 Hosp. Reimbursement Rate for William B. Kessler Memorial Hosp., 78 N.J. 564, 397 A.2d 656 (1979). The case mvolved a challenge to rulemaking rather than adjudication. Justice Handler's concurring opinion noted: "The rate-review proceedings under the Health Care Facilities Planning Act are designed in large measure to elicit quasi-legislative determmations analogous to prospective rate-making generally characteristic of regulated industries." $\mathrm{Id}$. at 576 77, 397 A.2d at 662 (Handler, J., concurring).

66. $I d$. at 578,397 A.2d at 663 (Handler, J., concurring).

67. Id. at $576-77,397 \mathrm{~A} .2 \mathrm{~d}$ at 662 .

68. $I d$. at 577,397 A.2d at 662 . 
ministrative expertise in resolving controversies and effectuating the policies of the statute. ${ }^{69}$

In order to invalidate an agency's decision that increased lospital costs do not justify increased reimbursements, the record from the agency's hearing must indicate that the party challenging the agency action "produced countervailing proofs sufficient to . . . establisls the reasonableness of these costs."70 Similarly, parties challenging denials of CONs-on the theory, for example, that coinpetition is appropriate-must demonstrate the desirability of the competition. Justice Handler's willingness to scrutinize the reasonableness of hospital costs mdicates that some judges may be willing to scrutinize the desirability of competition. Both mquires mvolve sensivity to the technical economic problems of the health care industry.

\section{Conclusion}

Because the 1979 amendments to the National Health Planning and Resources Development Act are recent, most states have yet to bring their CON statutes into line with the new federal requirements. Once this does occur, state health plans will take on greater significance in the statutory regulation of the development of health care industries. The 1979 amendments have transformed the state health plans into full-fledged administrative rules. As such, these plans will be subject to judicial review. Except with respect to blatant procedural errors, however, the riglit to judicial review of state liealtlı plans inay be little more than a fulcrum without a lever unless aggressive litigants can convimce courts to intervene substantively.

Douglas L. Carter

69. Id. at $578,397 \mathrm{~A} .2 \mathrm{~d}$ at 663 .

70. Id. at 579, 397 A.2d at 663 . 
